\title{
AUTONOMY, EXPERIENCE AND CONCEPTS: A STUDY IN EDUCATIONAL DISCOURSES
}

\author{
TERESA SIEK-PISKOZUB \\ Adam Mickiewicz University, Poznań \\ piskozub@amu.edu.pl \\ ARIADNA STRUGIELSKA \\ Nicholaus Copernicus University, Toruń \\ pieshau1@wp.pl
}

\begin{abstract}
The aim of this article is to investigate the impact of educational reforms launched in Poland in the last decade upon the notion of learner autonomy as evidenced by the results of a crosssectional study. Necessarily, standard definitions of the concept of autonomy will be re-defined against the background of socio-political reforms in the country and their reflections in syllabuses and curricula. Re-evaluating the notion of learner independence in the Polish context will be primarily viewed from the perspective of the learner; however, relevant comparisons with teachers' perceptions will be also provided. Employing methodological guidelines offered by Conceptual Metaphor Theory, conclusions will be drawn concerning the practicability of fostering learner autonomy in the Polish milieu.
\end{abstract}

KEYWORDS: Learner autonomy; conceptual metaphor; frames.

\section{Introduction}

Autonomy has long become a key notion among language practitioners, as has the need for greater learner independence finding its way into syllabuses and curricula. Poland met this challenge as late as 2001, when the launching of educational reforms shattered the prevailing system of authoritarian values. Naturally, learner-autonomy was duly highlighted within the new national curriculum. Now, several years after its inception into Polish schools, autonomy definitely reverberates across the educational network. The echoes of the reform can be heard in multifarious discourses (Pawlak 2004, 2008). On the one hand, there are various groups involved in the teaching/learning process - 
language theoreticians and practitioners, as well as students. Each sector voices their opinions. On the other hand, perceptions and conceptions have been de- and reconstructed as a result of the shaking of the foundations of Polish classrooms.

The aim of the current research is to hear the many critiques and views on autonomy in Polish educational institutions. Particular emphasis will be placed on the dynamics of learners' personal theories. If autonomy is really becoming an important element of Polish educational reality, the novelty of the experience should be reflected not only in the theoretical jargon but also in students' private hypotheses. Data collected from learners will be analyzed within Conceptual Metaphor Theory (Lakoff and Johnson 1980; Kövecses 2002; Schön 1993) with reference to coherence relations between their naïve images and the ideal cognitive model predicated by the reform. The underlying theme of the study will hence be to present a context-bound definition of the notion of autonomy. Naturally, standard characterizations of the concept should be discussed first.

\subsection{On defining autonomy}

The concept of learner autonomy has entered the educational scene of the previous century through a number of intertwining channels. Interest in constructivist philosophy as opposed to positivism influenced many social sciences such as sociology, cognitive psychology and also language education. The multifaceted influence of constructivism on the foreign language pedagogy was analyzed by Siek-Piskozub (2006). Fosnot (1996: ix) summarizes different forms of constructivism in educational studies as follows:

\footnotetext{
Based on work in psychology, philosophy, and anthropology, the theory describes knowledge as temporary, developmental, nonobjective, internally constructed, and socially and culturally mediated. Learning from this perspective is viewed as a self-regulatory process of struggling with the conflict between existing personal models of the world and discrepant new insights, constructing new representations and models of reality as human meaning-making venture with culturally developed tools and symbols, and further negotiating such meaning through cooperative social activity, discourse and debate.
}

Broadly defined by Holec (1979: 3) as "the ability to take charge of one's own learning", autonomy is viewed as a means of empowering individuals to function in a dynamic pluralistic society. Becoming an autonomous person is a developmental process. Little (1990: 7) observes that autonomy is

[e]ssentially a matter of the learner's psychological relation to the process and content of learning. We recognise it in a wide variety of behaviours as a capacity for detachment, critical reflection, decision-making, and independent action. The various freedoms that autonomy implies are always conditional and constrained, never absolute. 
Abbott (1996: 47) also emphasizes that true development starts in the mind. However, we need others to have experience with as " $[t]$ he insights, knowledge, and advice of others provide [us] with choices as well as stimulation" (Fanslow 1997: 166).

Nunan (1997) posits that autonomy works in different ways. He distinguishes five levels of learner autonomous activity, i.e. awareness, involvement, intervention, creation, and border crossing. Littlewood (1999) makes a different distinction: in proactive autonomy, individual interests help define learning goals, whereas in reactive autonomy, learners may not specify their own goals but nevertheless make decisions concerning the way of achieving them. Thus, autonomy is a construct denoting a complex phenomenon characterizing individuals and groups. Now, after many years of the debates over learner autonomy, Sinclair (2000) concludes that autonomy is a capacity which has a social as well as individual dimension. It involves a willingness on the part of the learners to take responsibility for their own learning; however, it is not simply a matter of placing learners in situations where they have to be independent. Crucial for the development of autonomy is a conscious awareness of the learning process, i.e. conscious reflection and decision making. However, promoting autonomy is not simply a matter of teaching strategies as it also has a political dimension. It is interpreted differently by different cultures. Autonomy can take place both inside and outside the classroom. The degrees of autonomy are unstable and variable from task to task. To better understand the concept, different research procedures have to be used in different learning contexts.

\section{The study}

The present study was conducted in order to test the applicability of standardized conceptions of learner autonomy within the Polish educational context. Therefore, in order to be able to comprehend and interpret the results, a multifaceted background needs to be introduced first. The study proper will thus be preceded by elucidating the sociopolitical reality instrumental in conducting the educational reforms. Next, teachers' reactions to the ensuing didactic reality will be presented. Section 2.1.3. will be devoted to expounding theoretical prerequisites behind the study, as well as establishing connections between ongoing research into Conceptual Metaphor Theory and the current study.

\subsection{Background to the study}

\subsubsection{The impact on educational reforms of socio-political changes in Poland}

With the ideological, economical and social changes in Poland, since the 1990s, teacher and learner autonomy has become an issue of interest to the new Polish educational authorities. This resulted in defining new core-curricula for general education, as well as 
opening the possibility of specifying subject-specific syllabuses for schools and coursematerials designers. Holistic learner development, where autonomy is an important objective, is repeatedly emphasized in core-curricula for the general education and subject-specific syllabuses at each educational level.

In 1988-89, the Polish educational system faced a challenge of changing language policy. Russian was abolished as an obligatory first foreign language, although it was not removed from schools. Fisiak (1994: 9) notes that

\footnotetext{
[t]he abolishing of Russian as an obligatory language in primary and secondary education and the consequent pressure from students and parents for English to be offered in every school created a challenge for the Polish educational authorities which could be met successfully only if sufficiently large numbers of teachers were provided quickly.
}

To facilitate foreign language teacher education, new educational institutions (state- and privately-owned) were founded to prepare teachers of English, German and French languages for the new concepts and practices. Various in-service teacher courses run by universities and state and local educational authorities are constantly being offered. All this is done in the hope of changing teaching practices ingrained under the previous totalitarian socio-political system. These changes were stimulated by various European projects aimed at promoting and facilitating plurilingualizm and intercultural competence of European citizens. Such projects include new language syllabuses, e.g. Threshold level 1990 (van Ek and Trim 1991), the idea of European Language Portfolio (Bajorek et al.2005; Bartczak et al. 2006), and the Common European Framework of Reference for Languages (Council of Europe 2001).

However, as Fisiak (1994: 7) rightly comments " $[t]$ ransferring educational innovations from one system to another is easy to initiate but difficult to carry out successfully. [...] Innovations and modifications coming from external sources must fit the existing system if they are going to succeed."

Thus, the challenge of fostering autonomy in Polish state schools has attracted many FL teachers' and researchers' attention. They report their experiences and research findings at conferences and/or in collective volumes (e.g. Pawlak 2004, 2008b; Wilczyńska 2002). Their findings help us to define the concepts of autonomy from the Polish perspective.

\subsubsection{Autonomy from the educator's perspective}

Michońska-Stadnik (2004), following Benson and Voller (1997), has analyzed three types of autonomy, namely technical (referring to the ability to use computer software and the internet in self-study), psychological (individual meaning-making in a given social context), and political (adjusting to the socio-political situation of the instructional 
context). These are cited by way of explaining why it is difficult to implement these modalities in the Polish context. The study findings reveal that despite declarations of readiness to accept autonomy in their classroom, only one of the five observed teachers actually implemented elements of autonomy in her/his classes. Moreover, students were not expected to take charge of their learning or to make their own decisions as to the choice of course-books. Michońska-Stadnik emphasizes that, for teachers, their own experience of learning was more important for them than the education they got during their methodology courses, an observation confirmed also by Kłębowka (2006). Added to this reluctance is a limitation imposed on them from outside the classroom. A political type of autonomy in the classroom, according to Michońska-Stadnik, has little chance of success. Although teachers are formally granted a certain degree of autonomy in choosing the syllabus or the course-book, they are often restricted by some external regulations. Yet, despite the generally pessimistic view emerging from the findings, Michońska-Stadnik believes that it is possible and necessary to develop learner autonomy, as it is not only important for school success but success in general.

The view that teachers do not always value autonomy in their classes is also shared by Wiśniewska (2003), who gave a course in learner autonomy for foreign language teachers, and as a follow up studied its impact on their practices. At the end of the study, many teachers admitted that learning about autonomy was a valuable experience; however, they were not very willing to implement it in their classroom. Their attitude toward autonomy was shaped by the following factors: teachers' beliefs about teaching/learning held before the training in enhancing autonomy procedures, as well as beliefs formulated in the course of the study; teachers' understanding of the concept; problems they encountered in teaching; institutional requirements (curricula, course-books, grades, etc.); lack of sufficient training; and the lack of a supportive environment.

Droździał-Szelest (2004) perceives language learning strategies as the key to learner autonomy and emphasizes the value of strategy training. In her opinion, the majority of learners are not aware of their learning abilities and are unable to use the acquired skills and determine their needs in terms of a foreign language or evaluate their own progress. The research conducted in the Polish context revealed also learners' adherence to the traditional model of teaching and their choice of learning strategies emerging from it. A study by Pawlak (2008) supports this observation for as much as $65 \%$ of respondents, who consisted of 134 of the 206 secondary school students surveyed, admitted they only prepare for tests and exams. Pawlak (2008: 137) observes that "even the modest goal of reactive autonomy is quite difficult to achieve since many learners are reluctant to assume greater responsibility for their learning". In a different study, $43 \%$ and $67 \%$ of respondents (first- and third-year secondary school students, respectively) claim that they study even if they do not have too (Strzałka and Ździebło 2008), a finding which supports the observation that still some learners do not voluntarily get involved in the language learning process or know how to do this. However, at the same time, the data contradict Pawlak's observation that the first year students declared readiness to accept responsibility more often than the second year students (Paw- 
lak 2008: 145-146). Studies by Strugielska (2008), Strugielska and Siek-Piskozub (2008) as well as the current research confirm that autonomy among secondary school students is a fluctuating tendency. While, on the whole, there is a noticeable increase in autonomous attitudes among learners, numerous inconsistencies within individual conceptual systems, possibly resulting from cognitive dissonance (Festinger 1957), often skew elicited data in such a way that ambiguous interpretations may emerge. Therefore, it seems advisable to look for individual as well as group coherence patterns.

Contributing to this deficient attitude toward learning are teaching materials which do not always assist teachers in this respect either, as observed by Krulak-Kempisty (2004) and Chudak (2005), who examined a sample of course-books for teaching German as a foreign language. The data were obtained by analyzing how well the selected materials measured up to established criteria (i.e., whether the course-book promoting autonomy actually activated the learner; whether it was transparent and open to the learner's interests and capabilities; whether it assisted and gave objective assessment of the learner's proficiency). Also used in this research was a questionnaire directed to teachers and learners. The results of both studies indicate that not all of the selected course-books support learner autonomy to the same extent. The situation is not much different at the tertiary educational level.

In a qualitative study, Górecka (2003) evaluated how academic discourse analysis in MA seminars impacted on the acquisition of argumentative competence by French philology students. The researcher identified the main types of intellectual activities which students were involved in, as well as teachers' expectations of students' attitudes and of their communicative and learning actions. She also discussed the problems which students encountered while participating in academic discussions. Out of this, she proposed a list of skills in the field of critical thinking, indispensable for seminar discussions. Her study noted major difficulties that included students' passive approach to learning, dependence on the teacher, and preference for fact-collecting knowledge with a weak narrative slant and for the traditional model of teaching/learning.

The study by Aleksandrzak (2006) addressed an attempt in EFL classes at raising university students' meta-awareness of learning strategies with the use of typologies proposed by Oxford (1990) and O'Malley and Chamot (1990) (e.g. group discussions on the learning problems, peer and self-evaluation, project work). The result was a change in the knowledge structure as revealed by self-evaluating interviews with the participants. Their self-diagnosis was reliable, as it was confirmed by external evaluation. The subjects managed to choose appropriate strategies for the difficulties they encountered, specific to their learning preferences. Some forms of self-reflection and selfanalysis (e.g. recordings and analysis of their speech for subsequent self-correction) appeared to be appreciated by all participants. They were also able to set individual goals in learning related to their present state of knowledge and anticipated needs. The researcher concluded that an attempt to involve learners in metacognitive activities brought about an important change in learner awareness and independence, which are important factors for developing learner autonomy and creativity. 
One can conclude from this brief overview that enhancing autonomy in Polish schools seems to be a problem. However, there is slowly growing evidence that Polish foreign language teachers are experimenting with new ideas at all levels of education. For example, Hoffman (2008) describes how she facilitates autonomy among 2-to-6year-old learners in her language school, involving them in choosing tasks, materials, design and project work. Koralewska (2008) reports that a majority of the 48 primary-, junior- and secondary-school teachers surveyed by her introduce project work into their classrooms despite the fact that it requires more effort on the part of the teacher. From her experience with foreign language classes at the university students, Cichon (2008) draws conclusions based on Internet resources.

Educators' perceptions and conceptions concerning learner autonomy will constitute the basis of comparison between expert and folk models of educational practice (Ungerer and Schmid 1996). To get data for such juxtaposition we will apply the methodological apparatus provided by Conceptual Metaphor Theory.

\subsubsection{Conceptual metaphor and educational practice}

Metaphor has always constituted an indispensable part of the inquiry into how people use language to express thought. Current research in Cognitive (Experiential) Linguistics emphasizes the conceptual potential of metaphor. According to Lakoff and Johnson (1980: 5), metaphor pervades everyday language as well as human thoughts and actions. The nature of its mechanism is to comprehend and experience one concept, typically more abstract, in terms of another one, which is directly emergent. Metaphorical understanding is achieved via establishing a set of correspondences (mappings) between the two domains involved.

Conceptual metaphors are closely tied to the cultural and social milieu in which they operate. According to Lakoff and Johnson (1980: 142), conventional metaphors define a particular socio-cultural status quo. The meaning of novel metaphors, on the other hand, is determined in part by the culture, and in part by the personal experience of the user. Vygotsky (1978) views conventional metaphors as important cultural artifacts products of a specific set of traditions - which, through social interactions, become adapted for use in the construction of personal understandings. However, as Guerrero and Villamil (2002: 99) rightly observe, metaphor appropriation does not consist in merely copying the metaphorical units sanctioned by a particular community. Culturally shared metaphors are subject to fluctuation due to various personal experiences of individuals and the multifarious social discourses they are exposed to.

Another key notion related to conceptual metaphors is coherence. According to Lakoff and Johnson (1980: 98-102), coherence relations between metaphorical constructs vary from perfect consistency to inferential links drawing upon shared entailments. Consequently, one of the most important aspects of a metaphor is the roles it creates for self and others. 
Conceptual metaphors are evidenced by metaphorical linguistic expressions, which testify to the validity of a given mapping between source and target domains. Describing teachers as open books, sources of wisdom or television sets may well be interpreted as linguistic manifestations of THE TEACHER IS A PROVIDER OF KNOWLEDGE conceptual metaphor.

Conceptual mappings are closely linked to the notion of generative metaphors. In a paper on the use of generative metaphors on social policy issues, Schön (1993: 138) claims that the "framing of problems often depends upon metaphors underlying the stories which generate problem setting and set the directions of problem solving". In other words, once the metaphor has been created, our thoughts are formulated and reshaped in the way imposed and constrained by the metaphor. More importantly, this process of creating and imposing mappings is related to the question of problem solving. Namely, metaphors we have been exposed to are frequently used manipulatively in order to direct us towards some predestined alternatives.

As a result, what is claimed here is not that metaphors should be avoided, as they are one of our most productive cognitive processes, in terms of comprehension, but rather that "we ought to become critically aware of these generative metaphors" (Schön 1993: 139), as they generate our framing of different issues. As will be evidenced by the results of the current study, the persuasive power of generative metaphors and their role in creating new realities should not be underestimated.

In recent years, numerous studies on the metaphorical nature of educational practices have become available (Cameron and Low 1999, 1999a; Cortazzi and Jin 1999; de Guerrero and Villamil 2002; Martinez, Sauleda and Huber 2001). The analyses offered can be defined along a distinctive set of parameters. Firstly, they are teachercentered, since the data is elicited from the instructors alone. Moreover, metaphorical linguistic expressions tend to form perfect models with easily detectable coherence relations. Thus, if I am a shepherd, my students must be sheep. If I am a gardener, my students are plants. In the same vein, Dakowska (2005) stipulates that the CLASSROOM AS A HOTHOUSE metaphor necessarily entails the images of the TEACHER AS A GARDENER and STUDENTS AS PLANTS. Similarly, despite admitting a variety of stimuli responsible for the emergence of an image of the teacher, de Guerrero and Villamil (2002) provide a uniform string of concepts entailed by teacher-oriented metaphors. For instance, the TEACHER AS AN ARTIST conceptualization leads to necessary inferences concerning the learner (as raw material) and the process of teaching (as creating).

This teacher-dominated figurative focus has been recently altered by a number of studies into learners' conceptions of the classroom (Siek-Piskozub and Strugielska 2007; Strugielska 2008; Strugielska and Siek-Piskozub 2008). Again, there are distinct parameters which can be identified from research into learners' personal theories of education. Firstly, the data suggest an overall lack of coherence, which is manifested at the level of an individual respondent as well as across a particular group. For instance, teachers/parents are grouped together with learners/discoverers and accompanied by 
prison-like classroom images. Another characteristic feature of learners' conceptions is an apparent emergence of sub-models within their non-expert taxonomies. For example, teachers-as-leaders can be clustered with learners-as-travelers. Likewise, learningas-consumption matches the model of teaching-as-providing knowledge. Such submodels, which are relatively frequent in the data (Strugielska in press), point to a viable option of considering educational discourse as reflecting small-scale conceptual links rather than overarching, idealized connections. Another parameter of learners' concepts is their apparent sensitivity to changes in educational experience. Moreover, such alterations should be viewed as asymmetrical since certain conceptual elements tend to be more prone to fluctuation than others. As Siek-Piskozub and Strugielska (2007) convincingly demonstrate, the concept of the teacher will be most readily amended within students' cognitive networks in response to new educational experience. On the other hand, the construct of the learner can be described as fairly resistant to new experiential stimuli. Consequently, the current study will be focused on the concept of the teacher and its susceptibility to change in Poland as the educational scene changes.

To sum up, the above considerations lead to the following implications for the present study: due to their internal dynamics and non-idealized nature, learners' conceptual metaphors stipulated by educational experience are an insightful tool for analyzing the impact of the new national curriculum upon learner autonomy.

\subsection{Methodology}

As noted in Section 2.1.3 above, the procedural thrust for the present analysis comes from Conceptual Metaphor Theory. Hence, the data will be interpreted and grouped according to headings provided by conceptual generalizations. However, it also seems plausible to perspectivize the responses with reference to a particular frame they evoke. Consequently, for the sake of the current study, a frame will be defined as an underlying context which renders educational experience coherent by enabling the interpreter to distinguish reference elements within an otherwise unstructured flow of occurrences. Thus, in our view, the process of discovering learners' representations of autonomy can be facilitated by an interplay of three metaphorically based frames.

First of all, there is the learning frame which draws upon the three dominant educational paradigms: behaviorist, constructivist and socio-historical (cf. Martinez, Sauleda and Huber 2001). The behaviorist perspective interprets knowledge as a set of relations resulting from experience. Consequently, the process of learning is reduced to generating new connections between the units. By entailment, the role of individual contributions or peer collaboration is of no significance. From a constructivist point of view, knowledge consists of interconnected abstract representations which are the product of active contributions by individuals, who either transform the already existing matrixes 
or form original ones through inductively filtering new experiences. The sociohistorical perspective, according to Bruner (1996), views knowledge as distributed among individuals in a social community. Moreover, knowledge is defined as not only a set of mental schemas but also a collection of artefacts. Consequently, learning is seen as a dialogical interaction which benefits not only individuals but also the community. Hence, activity and authentic participation are seen as necessary prerequisites for the successful acquisition of knowledge and skills. As indicated by Tobin and Tippins (1996), educational practice, viewed from the position of social constructivism, is intertwined with the notion of fighting in order to establish an equitable distribution of power between the teacher and the learner. Consequently, the learning perspective becomes inextricably connected with the social frame.

The second frame proposed for the sake of the current study hinges upon the notion of classroom dynamics. Thus, the social frame is closely related to the concept of notion of classroom climate, as defined by Williams and Burden (1997: 196-197). Consequently, imposing the social frame on the data should uncover the degree of teacher control. For instance, the linguistic metaphor "the teacher is like an army commander because s/he gives orders" would be generalized to the TEACHER AS A SUPERIOR conceptual metaphor, and, consequently, interpreted primarily against the social frame.

Finally, there is the axiological frame, which allows subjective opinions and evaluations to enter metaphorical concepts. For example, "the teacher is a guide because s/he gives directions" will be taken as a neutral statement. However, "the teacher is a miner because his/her work is tedious and purposeless" will be taken as an evaluative linguistic example. As indicated by Langacker (1987), subjectification entails vantage-point re-arrangements and, consequently, leads to changes within cognitive models. In other words, a non-objective perspective, or the presence of skewed elements within conceptualizations, may well trigger a process of conceptual disintegration and deconstruction. In other words, axiologically loaded comments point to a possible rejection of an existing model. A further step would be formulating alternative solutions, or generative metaphors, as evidenced by "the teacher is like a friend because $\mathrm{s} / \mathrm{he}$ should be one".

These three possible perspectives given above should not be taken in isolation. Instead, we are going to demonstrate that they are dynamic and interrelated, thus forming a particular macro-frame. Moreover, the frames will be related to the notion of learner autonomy in order to highlight their methodological validity. Consequently, the perspective imposed by the learning paradigm will be attributed to psychological autonomy, as defined in Section 2.1.2. The social frame will be taken as indicative of political autonomy, whereas the axiological perspective will help us to distinguish elements of generative autonomy, which may well be understood as learners' "wishful thinking". In other words, generative metaphors, as emerging from the current data, are not fullyfledged conceptualizations. Instead, they are to be viewed as indicative of learners' attitudes promoting higher autonomy in Poland, particularly at institutional levels. 


\subsection{Goals and procedures}

The overall aim of the current study, as already indicated in Section 2.1.3 above, is to discover the impact of the autonomous paradigm upon the conceptual systems of secondary school graduates in a cross-sectional study. A pre-requisite procedure then is to capture and systematize learners' linguistic and conceptual reactions to their changing educational experience. ${ }^{1}$

The subjects in this study were three groups of English philology students at Nicolaus Copernicus University of Torun, Poland. The project was launched in October 2005, and continued till October 2007, involving 100 students altogether: that is, 24, 36, and 40 in the three groups, respectively. In one group were first year students. They were all examined at the beginning of a particular academic year to make sure that the new experience of the university context did not interfere with the subjects' conceptual networks formed under the influence, among others, of secondary school stimuli.

In the course of the study, each group of learners was asked to complete the following five sentences, commonly included in diagnoses of a similar nature (Cortazzi and Jin 1999; Górecka 2003), namely: The teacher is like... because...; Teaching is like... because...; The learner is like... because...; Learning is like... because...; The classroom is like... because.... This exercise provided linguistic data describing the learners' experience from secondary-level education. The results were then evaluated and grouped according to the standard procedures adopted for metaphorical assemblies described in de Guerrero and Villamil (2000). Since metaphor analysis involves "collecting examples of linguistic metaphors used to talk about the topic [...] generalising from them to the conceptual metaphors they exemplify, and using the result to suggest understandings or thought patterns which construct or constrain people's beliefs and actions" (Cameron and Low 1999a: 88), we systematically examined elicited linguistic expressions in order to uncover the underlying conceptual generalizations. As stated in Section 2.1.3, metaphorical linguistic expressions are taken as examples of more wideranging conceptual metaphors. Consequently, our first step in the analysis was to make a list of the linguistic metaphors supplied by the participants. Most of the data were in the form of similes, often with explanatory comments, such as "the teacher is like a priest because only s/he talks and the students must listen". We then proceeded to look for the analyzable parts within our data, pinpointing the most salient features and establishing similarities among them. For instance, "the learner is like a child because s/he does not know what to do" highlights the student's helplessness whereas the formulation "the learner is like a child because s/he is growing up and gaining independence" taps to the student's autonomous features. In other words, we paid special atten-

\footnotetext{
${ }^{1}$ Educational experience need not to be understood in the narrow sense of the term here. On the contrary, we postulate that autonomy is an attitude which permeates various spheres of life. Hence, particularly if education is viewed from the socio-historical perspective (Section 2.2), school education is will be taken as one of the possible contexts promoting autonomy.
} 
tion to our respondents comments, since it was there that the relevant attributes were most often espoused. Considering the process of metaphor appropriation (see Section 2.1.3), it is only natural that the data were permeated by elements of the professional jargon. Hence, it seemed essential to look for reinforcement to the many conventional metaphors provided in the form of explanatory comments. Once we examined the vocabulary employed by the participants in their metaphorical expressions, we grouped the linguistic data according to the conceptual metaphor they might represent. To make our classification more verifiable, we tried to employ a number of conventional conceptual metaphors, e.g. THE TEACHER IS A GUIDE, discussed at length in the literature (see, for instance, Cortazzi and Jin 1999). Our final procedure was to look for coherence relations in the data. Consistencies within a particular group of participants were particularly important for the results presented in this study. Consequently, we tried to establish a dominant conceptual metaphor for the concept of, for instance, the teacher in each of the three groups.

\subsection{Results and discussion}

As outlined in Section 2.1.3 above, metaphorical linguistic expressions relating to how the teacher is constructed will be taken as primary indicators of possible fluctuations in naïve taxonomies. Consequently, Table 1 below presents our tentative groupings of the students' responses. Set One corresponds to the first group of participants, examined in October 2005, Sets Two and Three denote the two subsequent groups. The conceptual metaphors are numbered to facilitate cross-referencing and each is presented together with the number of answers and a rough percentage. It should be noted, however, that since not all the data elicited could be classified as metaphorical comparisons, the numbers added may not constitute a perfect 100 percent. Moreover, some possibly ambiguous conceptual metaphors are followed by specific illustrations to highlight the reason for adopting a particular frame.

As stipulated in Section 2.2, the data should be interpreted against three frames. First, the results viewed against the background of the learning frame will be presented. Naturally, since the three frames are closely intertwined, adopting a particular perspective may sometimes seem arbitrary. Therefore, each of the learning perspectives below is accompanied by the salient attributes which served as our guidelines in subclassifying a particular conceptual metaphor. The results interpreted against the learning frame can be summarized in the following way:

Set One:

- behaviorist (lines: 1, 2) (65\%) (attributes highlighted: teachers' responsibility, learners' helplessness);

- constructivist (lines: 4, 6) (12.4\%) (attributes highlighted: the teacher as a facilitator/an assistant). 
Table1. The concept of the teacher

\begin{tabular}{|c|c|c|}
\hline Set One: $2005 / 2006(24)$ & Set Two: $2006 / 2007$ (36) & Set Three: $2007 / 2008(40)$ \\
\hline 1. THE TEACHER AS A & THE TEACHER AS A & THE TEACHER AS A \\
\hline LEADER (A GUIDE) (11) & LEADER (12) & SUPERIOR/ENEMY (20) \\
\hline $45 \%$ & $33 \%$ & $50 \%$ \\
\hline 2. THE TEACHER AS A & THE TEACHER AS A & THE TEACHER AS AN \\
\hline GUARDIAN (e.g. a par- & GUARDIAN (assistant) (6) & ADVISOR (12) \\
\hline $\begin{array}{l}\text { ent) (5) } \\
20 \%\end{array}$ & $16 \%$ & $30 \%$ \\
\hline 3. THE TEACHER AS A & THE TEACHER AS A & THE TEACHER AS AN \\
\hline SUPERIOR (3) & SUPERIOR (6) & AMBIVALENT BEING (AN \\
\hline $12 \%$ & $16 \%$ & $\begin{array}{l}\text { ENEMY/AN ADVISOR) (5) } \\
12 \%\end{array}$ \\
\hline 4. THE TEACHER AS & THE TEACHER AS A & THE TEACHER AS A \\
\hline AN OBJECT (e.g. a road- & TOOL (e.g. a TV set) (6) & LEARNER (2) \\
\hline sign) (3) & $16 \%$ & $8 \%$ \\
\hline \multicolumn{3}{|l|}{$12 \%$} \\
\hline 5. THE TEACHER AS A & \multicolumn{2}{|l|}{ THE TEACHER AS A } \\
\hline FIGHTER (1) & \multicolumn{2}{|l|}{ FIGHTER } \\
\hline $0.4 \%$ & \multicolumn{2}{|l|}{ (A CHALLENGER) (3) } \\
\hline & \multicolumn{2}{|l|}{$0.8 \%$} \\
\hline 6. THE TEACHER AS & \multicolumn{2}{|l|}{ THE TEACHER AS AN } \\
\hline AN ORGANIZER (1) & \multicolumn{2}{|l|}{ OBJECT (3) } \\
\hline $0.4 \%$ & \multicolumn{2}{|l|}{$0.8 \%$} \\
\hline
\end{tabular}

Set Two:

- behaviorist (lines: 1, 4) (49 \%) (attributes highlighted: teachers' responsibility, transmission of knowledge);

- constructivist (lines: 2, 6) (16.8\%) (attributes highlighted: facilitating, assisting).

Set Three:

- constructivist (line: 2) (30\%);

- socio-historical (line: 4) (8\%) (attributes highlighted: collaboration, negotiation).

The dominant perspective within the first set is behaviorist (65\% of the responses), whereby teachers are viewed as setting routines, defining goals and taking the full responsibility for the educational process. Learners' helplessness thus emerges and is only slightly balanced by the two constructivist metaphors: TEACHER AS AN OBJECT and THE TEACHER AS AN ORGANIZER (12.4\%). As far as the socio-historical perspective is concerned, its role in the first set is at best marginal (THE TEACHER AS A FIGHTER $-0.4 \%$ ). When we move to Set Two, the dominant conceptual metaphors are deceptively similar. It is only through analyzing the students' comments that differences can be spotted. Consequently, while TEACHERS/LEADERS (i.e. who-set- 
routines-and-define-goals) is still within the behaviorist paradigm, TEACHERS/ GUARDIANS elicits constructivist notions of facilitation and assistance. However, TEACHERS-AS-TOOLS (16\%) is again to be interpreted within the empiricist context. In Set Three, the dominant metaphor is connected with the social frame, and will thus be discussed below. TEACHERS-AS-LEADERS/ADVISORS is definitely a constructivist conceptualization, whereby helping is often connected with learning strategies. An interesting category is definitely THE TEACHER AS AN AMBIVALENT BEING, where, on the one hand, instructors are perceived as enemies; on the other, however, they are admired for their expertise. We postulate that the above polarization is motivated by two apparently different contexts against which teachers are set. In other words, if educators are perceived against the institutional background, they are placed within the social frame. Hence, the resulting duality points to students' rising awareness concerning the educational process. Finally, TEACHERS/LEARNERS, viewed as uncertain and constantly developing their skills, should be placed within the fuzzy area between constructivist and socio-historical frames.

If the results are interpreted within the social frame, the following regularities can be observed:

Set One:

- teacher-centered (lines: 3, 5) (12.4 \%); (lines: 1, 2) (65\%);

- learner-centered (lines: 4,6$)(12.4 \%)$.

Set Two:

- teacher-centered (lines: 3, 5) (16.8\%); (lines: 1, 4) (49\%);

- learner- centered (lines: 2, 6) (16.8\%).

Set Three:

- teacher-centered (line 1) (50\%);

- learner-centered (line 3) (30\%);

- equal (line 4) (8\%).

The first comment to be made concerns teacher-centered groupings in Sets One and Two. As indicated by the above clusterings, a clear division between frames - in this case, between learning and social perspectives - is often hard to distinguish, which was duly emphasized in Sections 2.1.3 and 2.2 above.

On a more particular note, it is interesting to observe that although the classroom is teacher-dominated in all the three sets, qualitative differences, in the form of the respondents' comments, are easy to detect. Specifically, while students' in the first group are fairly happy with being controlled, this tendency decreases with time. Respondents in the third group are prone to finding teacher-controlled classrooms undesirable, which is closely linked to the axiological perspective.

The axiological frame is best captured via the most representative comments. Consequently, these are offered as a summary of the results within the third frame: 
Set One:

(1) The teacher is a guide because s/he gives directions. (neutral)

(2) The teacher is a guide because s/he organizes interesting trips and provides useful comments. (evaluative/positive)

Set Two:

(3) The teacher is a miner because her/his work is tedious and purposeless. (evaluative/negative)

Set Three:

(4) The teacher is like a beast/an executioner because s/he tells you what to do. (evaluative/extremely negative)

(5) The teacher is like a friend because it should be like this. (generative)

As already implied above, the social climate in Set One is predominantly positive. Students tend to be neutral with reference to their educational context and even if they venture an evaluative comment, it is positive, as if accepting the surrounding reality. In contrast, students in Set Two provide evaluations, mostly in the form of negative comments, e.g. teaching is purposeless, it causes suffering, it is tedious. Interestingly, evaluative remarks in Set Three are often in the form of instructions based on negative perceptions, e.g. teachers pose a threat to students' development so something should be done. Therefore, in view of Schön's interpretation provided in Section 2.1.3 above, they can be classified as generative metaphors since they provide possible solutions to metaphorically viewed problems.

An interplay between frames and metaphors is presented in Table 2 below.

Table 2. Frames and metaphors - a cross-sectional perspective

\begin{tabular}{|c|c|c|}
\hline Set One & Set Two & Set Three \\
\hline $\begin{array}{l}\text { LEARNING FRAME: } \\
\text { BEHAVIOURIST } 65 \%\end{array}$ & BEHAVIOURIST 49\% & $\begin{array}{l}\text { CONSTRUCTIVIST } 30 \% \\
\text { SOCIO-HISTORICAL } 8 \%\end{array}$ \\
\hline $\begin{array}{l}\text { SOCIAL FRAME: } \\
\text { TEACHER- } \\
\text { CONTROLLED }(77.4 \%)\end{array}$ & $\begin{array}{l}\text { TEACHER- } \\
\text { CONTROLLED (65.8\%) }\end{array}$ & $\begin{array}{l}\text { TEACHER- } \\
\text { CONTROLLED (50\%) } \\
\text { LEARNER- } \\
\text { CONTROLLED }(30 \%) \\
\text { EQUAL }(8 \%)\end{array}$ \\
\hline $\begin{array}{l}\text { AXIOLOGICAL } \\
\text { FRAME: } \\
\text { NEUTRAL/POSITIVE } \\
\text { (over } 50 \% \text { ) } \\
\text { NEGATIVE (about } 20 \% \text { ) }\end{array}$ & NEGATIVE (over 20\%) & $\begin{array}{l}\text { NEGATIVE/ GENERA- } \\
\text { TIVE (over } 50 \% \text { ) } \\
\text { POSITIVE (about 40\%) }\end{array}$ \\
\hline
\end{tabular}


An overall conclusion emerging from Table 2 above can be formulated as follows: while cross-sectional changes between Sets One and Two can be reduced to quantitative ones, the discrepancy between the first two groups and Set Three concerns qualitative alterations, often pointing to a possible conceptual duality within the respondents.

\subsection{Micro-conclusions - implications for learner autonomy}

As stated in Section 2.1, the cross-sectional study presented above was to determine the possible impact of the changing educational reality in Poland upon students' conceptualizations related to their learning experience. If, as stipulated in Section 2.2, perspectivizing frames are indicative of learner autonomy, be it psychological, political (institutional) or generative, the following quantitative and qualitative changes can be observed on the basis of the current data:

Table 3. Changes in learner autonomy across frames

\begin{tabular}{|c|c|c|}
\hline Set One & $\bar{v}$ & Set Three \\
\hline $\begin{array}{l}\text { LEARNING FRAME: } \\
12.4 \%\end{array}$ & $16.8 \%$ & $38 \%$ \\
\hline $\begin{array}{l}\text { SOCIAL FRAME: } \\
12.4 \% \\
\end{array}$ & $17.6 \%$ & $44 \%$ \\
\hline $\begin{array}{l}\text { AXIOLOGICAL FRAME: } \\
\text { neutral/evaluative }\end{array}$ & $\begin{array}{l}\text { evaluative/implicitly gen- } \\
\text { erative }\end{array}$ & $\begin{array}{l}\text { evaluative/explicitly gen- } \\
\text { erative }\end{array}$ \\
\hline
\end{tabular}

Alterations across the learning frame indicate that students tend to abandon the role of passive recipient in favor of becoming an independent explorer. Hence, learner autonomy at the level of an individual can be taken as developing. Within the social frame, complacent submissiveness yields to conscious questioning. Psychological autonomy, as defined in Section 2.1, is then inextricably connected with independence at the social and institutional level. The generative perspective, explicit in the respondents' comments, signals a clear shift from neutrality to de-conceptualization and reframing. In other words, psychological sovereignty evolves, leading to generative autonomy.

All in all, the above-presented results seem rather striking since they seem to point to a significant change within learners' personal theories within a relatively short timespan. However, if we interpret the increase in autonomous attitudes against a broader background, the results seem far more convincing. In other words, gaining autonomy should be understood as a process which can be only partly facilitated by school. According to Trebbi (2008), we should move beyond the notion of teacher-stipulated autonomy. The concept of "pedagogy for autonomy" regards schools and teachers as 
frequent obstacles on the learners' way to becoming autonomous. Interestingly, a similar image emerges from the current data.

\section{Conclusions}

The aim of this study was to discover the possible impact of the autonomous paradigm upon the conceptual systems of secondary school graduates. Assuming that conceptual metaphors can provide insight into personal theories, we intended not only to study the subjects' perceptions of the broadly-conceived educational reality but also postulate some significant alterations in their responses, which seemed intertwined with the recent changes in Poland. To this end, a cross-sectional study was conducted, by means of which students' reactions to fostering autonomous attitudes were to be captured, systematized, and perspectivized.

The results of the study confirm that at the level of students' conceptions, changes towards autonomizing individuals are perceptible. However, this shift should definitely be seen as gradual and asymmetrical. Therefore, while the concept of the teacher is easily re-molded within the learning frame, changes imposed by the axiological perspective and summarized in Table 2 above are far more subtle.

Another conclusion to be drawn from the study concerns the students' rising awareness of educational practices and their own growing tendency towards autonomous thinking, as presented in Table 3 above. Hence, it can be postulated that learner autonomy evolves towards whole-person independence.

At the same time, however, the limits of autonomy can be detected. It is particularly the data in Set Three that indicate a specific conceptual duality among the respondents. That is, the results presented in Table 2 clearly indicate that, while most students find teacher-controlled classrooms a negative occurrence, as many as $40 \%$ are happy with this social structure. Personal anxiety, as well as an overall incapability of taking control of one's own life, may well be responsible for the skewed distribution of responses.

As far as autonomy at the institutional level is concerned, we can observe another dissonance. That is, while teachers are highly respected and admired when viewed as knowledgeable individuals, learner perceptions deteriorate when the context evoked is that of an educational institution.

All in all, the results emerging within the third group of respondents seem to be particularly telling about possible future directions in the autonomizing of Polish educational contexts, including our schools and classrooms. The clear polarization of responses, as presented in Table 3, indicates that many Polish students may not be ready to become autonomous. What is more, it may well be the case that Polish schools are not prepared to foster autonomy. Learners' responses are largely confirmed by what can be extracted from teachers' discourse reported in Section 2.1.2 above. However, learner autonomy can only be developed if teachers will feel the need to be autonomous themselves. Some teachers have already found their way to developing their own autonomy 
and fostering that of their learners. Others will eventually join in as the issue has been much debated recently.

\section{REFERENCES}

Abbott, G. 1996. "Development, education, and English language teaching”. In: Hedge, T and N. Whitney (eds.). 43-52.

Aleksandrzak, M. 2006. "Rola wiedy metakognitywnej i strategii metakognitywnych w kształtowaniu autonomii uczących się" [The role of metacognitive knowledge and metacognitive strategies in enhancing learner autonomy]. Neofilolog 26. 4-16.

Bajorek, A., I. Bartosz-Przybyło, M. Pamuła and D. Sikora-Banasik. 2006. Europejskie portfolio językowe dla dzieci od 6 do 10 lat [A European language portfolio for children aged 6 to 10 years]. Warszawa: Centralny Ośrodek Doskonalenia Nauczycieli.

Bartczak, E., Z. Lis, I. Marciniak and M. Pawlak. 2005. Europejskie portfolio językowe dla uczniów szkół ponadgimnazjalnych [A European language portfolio for secondary schools]. (2nd pilot edition.) Warszawa: Centralny Ośrodek Doskonalenia Nauczycieli.

Benson, P and P. Voller (eds.). 1997. Autonomy and independence in language learning. London: Longman.

Bruner, J. 1996. The culture of education. Cambridge, MA: Harvard University Press.

Cameron, L and G. Low. 1999. "Metaphor". Language Teaching 32. 77-96.

Cameron, L and G. Low (eds.). 1999a. Researching and applying metaphor. Cambridge: Cambridge University Press.

Chudak, S. 2005. Lernerautonomie fördernde Inhalte in ausgewählten Lehrwerken DaF für Erwachsene. [Unpublished PhD dissertation, Adam Mickiewicz University, Poznań.]

Cichoń, M. 2008. "Wykorzystanie źródeł internetowych w rozwijaniu samoświadomości i samoocenny uczniów (na przykładzie materiałów audiowizualnych telewizji frankofońskiej TV5)" [Using Internet resources for developing learners' self-awareness and self-evaluation (on the example of audiovisual materials from Francophone TV5)]. In: Pawlak, M. (ed.). 345-353.

Cortazzi, M and L. Jin. 1999. "Bridges to learning: Metaphors of teaching, learning and language". In: Cameron, L. and G. Low (eds.). 149-176.

Council of Europe. 2001. Common European framework of reference for languages: Learning, teaching, assessment. Cambridge: Cambridge University Press.

Dakowska, M. 2005. Teaching English as a foreign language: A guide for professionals. Warszawa: Wydawnictwo Naukowe PWN.

Droździał-Szelest, K. 2004. "Strategie uczenia się języka obcego: Badania a rzeczywistość edukacyjna" [Foreign language learning strategies: Research and educational reality]. In: Pawlak, M. (ed.). 31-34.

Fanselow, J.F. 1997. "Post card realities". In: Casanave, C.P. and S. R. Schecter (eds.), On becoming a language educator. Mahwah, NJ: Lawrence Erlbaum. 157-172.

Festinger, L. 1957. A theory of cognitive dissonance. Stanford, CA: Row, Peterson and Company.

Fisiak, J. 1994. "Training English language teachers in Poland: Recent reform and its future prospects". In Gough, C. and A. Jankowska (eds.), Directions towards 2000. Guidelines for the teaching of English in Poland. Poznań: Instytut Filologii Angielskiej UAM. 7-15.

Fosnot, C.T. 1996. Constructivism: theory, perspectives, and practice. New York: Teachers College Press, Columbia University. 
Górecka, J. 2003. La communication académique orale et le développement de la pensée critique en contexte exolingue. [Unpublished PhD dissertation, Adam Mickiewicz University, Poznań.]

Guerrero, M.C.M. and O.S. Villamil. 2000. "Exploring teachers' roles through metaphor analysis". TESOL Quarterly 34. 341-351.

Hedge, T. and N. Whitney (eds.). 1996. Power, pedagogy and practice. Oxford: Oxford University Press.

Holec, H. 1979. Autonomy and foreign language learning. Nancy: Council of Europe.

Kłębowska, M. 2006. "Transferring ELT knowledge to the classroom - Results of a study". Glottodidactica 32. 159-171.

Hoffman, A. 2008. "Promowanie autonomii w nauczaniu języka obcego wśród dzieci w wieku przedszkolnym" [Promoting autonomy in foreign language teaching of children in kindergarten]. In: Pawlak, M. (ed.). 235-244.

Koralewska, E. 2008. "Metoda projektu w metodyce nauczania języków obcych" [The project method in foreign language methodology]. In: Pawlak, M. (ed.). 207-218.

Kövecses, Z. 2002. Metaphor: A practical introduction. Oxford: Oxford University Press.

Krulak-Kempisty, E. 2004. Autonomizacja uczącego się a koncepcje wybranych podręczników do nauczania języka niemieckiego jako obcego [Learner autonomization and the concepts of selected coursebooks for German language teaching]. [Unpublished PhD dissertation, University of Gdańsk.]

Lakoff, G and M. Johnson.1980. Metaphors we live by. Chicago: The University of Chicago Press.

Langacker, R. 1987. Foundations of cognitive grammar. (Vol. 1: Theoretical prerequisites.) Stanford: Stanford University Press.

Little, D. 1990. "Autonomy in language learning. Some theoretical and practical considerations". In: Gathercole, M. (ed.), Autonomy in language learning. London: CiLT. 7-15.

Littlewood, W. 1999. "Defining and developing autonomy in East Asian context". Applied Linguistics 20. 71-94.

Martinez, M.A., N. Sauleda and G.L. Huber. 2001. "Metaphors as blueprints of thinking about teaching and learning". Teaching and Teacher Education 17. 965-977.

Michońska-Stadnik, A. 2004. "Autonomia ucznia 400 lat po Galileuszu, czyli szansa dla odpowiedzialnych" [Learner autonomy 400 years after Galileo, or a chance for the responsible]. In: Pawlak, M. (ed.). 11-18.

Nunan, D. 1997. "Designing and adapting materials to encourage learner autonomy”. In: Benson, P. and P. Voller (eds.), Autonomy and independence in language learning. London: Longman. 192-203.

O'Malley, J.M. and A.U. Chamot. 1990. Learning strategies in second language acquisition. Cambridge: Cambridge University Press.

Oxford, R. 1990. Language learning strategies: What every teacher should know. Boston, MA: Heinle and Heinle Publishers.

Pawlak, M. (ed.). 2004. Autonomia w nauce języka obcego [Autonomy in foreign language education]. Poznań and Kalisz: Wydział Pedagogiczno-Artystyczny UAM Poznań.

Pawlak, M. 2008a. "Autonomia w nauce języka angielskiego w liceum - Diagnoza, analiza, wnioski" [Autonomy in English language learning in secondary schools - Diagnosis, analysis and conclusions]. In: Pawlak, M. (ed.). 137-157.

Pawlak, M. (ed.). 2008b. Autonomia w nauce języka obcego - Co osiagnęliśmy i dokąd zmierza$m y$ [Autonomy in foreign language education - What has been accomplished and what are the directions]. Poznań and Kalisz: Wydział Pedagogiczno-Artystyczny UAM Poznań. 
Schön, D.A. 1993. "Generative metaphor: A perspective on problem setting in social policy". In: Ortony, A. (ed.), Metaphor and thought. New York: Cambridge University Press. 137-163.

Siek-Piskozub, T. 2006. "Social constructivism in foreign language education". Acta Universitatis Nicolai Copernici: English Studies XIII. 11-25.

Siek-Piskozub, T and A. Strugielska. 2007. "Jak kształcić nauczyciela autonomicznego. Historia pewnego seminarium" [How to educate an autonomous teacher. A history of one seminar]. In: Jodłowiec, M. and A. Niżegorodcew (eds.), Dydaktyka języków obcych na początku XXI wieku [Foreign language didactics at the beginning of the 21 st century]. Kraków: Wydawnictwo Uniwersytetu Jagiellońskiego. 337-346.

Sinclair, B. 2000. "Learner autonomy: The next phase?”. In: Sinclair, B., I. McGrath and T. Lamb (eds.), Learner autonomy, teacher autonomy: Future directions. Harlow: Longman. 4-14.

Strugielska A. 2008. "The teacher, the learner, and the classroom as reflections of contemporary cultural models: A study in metaphorical conceptualizations". In: Buchholtz, M., T. SiekPiskozub, D. Pestka and K. Więckowska (eds.), Acta Universitatis Nicolai Copernici, English Studies XV. 99-110.

Strugielska, A. (in press). "Metaphorical reflections of learners' educational experience-Coherence relations and internal dynamics".

Strugielska, A and T. Siek-Piskozub. 2008. "The teaching/learning experience at the university level - A case study in educational discourse”. In: Wąsik, Z. and T. Komendziński (eds.), Metaphor and cognition. Philologica Wratislaviensia: From grammar to discourse. Frankfurt/Main: Peter Lang. 117-131.

Strzałka, A. and K. Ździebło. 2008. "Autonomia ucznia w polskiej szkole średniej - Z notatnika metodyka anglisty i nie tylko" [Learner autonomy in the Polish secondary school - From a notebook of an English teacher-educator and more]. In: Pawlak, M. (ed.). 187-196.

Tobin, K., and D. Tippins. 1996. "Metaphors as seeds for conceptual change and the improvement of science teaching". Science Education 80(6). 711-730.

Trebbi, T. 2008. "Beyond the notion of teacher autonomy". (Paper read at AILA 2008 - The 15th World Congress of Applied Linguistics, Essen, Germany.)

Ungerer, F and H.-J. Schmid. 1996. An introduction to cognitive linguistics. London: Longman. van Ek, J.A. and J.L.M. Trim. 1991. Threshold level 1990. Strasbourg: Council of Europe.

Vygotsky, L.S. 1978. Mind in society: The development of higher psychological processes. Cambridge, MA: Harvard University Press.

Wilczyńska, W. (ed.). 2002. Autonomizacja w dydaktyce języków obcych. Doskonalenie się w komunikacji ustnej [Autonomization in foreign language didactics. Improving oral communication]. Poznań: Wydawnictwo Naukowe UAM.

Williams, M and R.L. Burden. 1997. Psychology for language teachers. Cambridge: Cambridge University Press.

Wiśniewska, D. 2003. Introducing autonomy in the foreign language classroom: Qualitative study on teachers' practice and problems. [Unpublished $\mathrm{PhD}$ dissertation, Adam Mickiewicz University, Poznań.]

Address correspondence to:

Teresa Siek-Piskozub

School of English, Adam Mickiewicz University

al. Niepodległości 4

61-874 Poznań

Poland

piskozub@amu.edu.pl 